\title{
EDITORIAL
}

\section{Soluble IL-18 receptor complex: a new star in the firmament of rheumatoid arthritis diagnosis?}

\author{
Fons AJ van de Loo* \\ See related research by Takei et al., http://arthritis-research.com/content/13/2/R52
}

\begin{abstract}
It has long been recognized that laboratory tests are useful in the diagnosis of disease and to monitor treatment outcome. Their performance has become even more demanding with the development of personalized medicine. In patients with rheumatoid arthritis (RA) the standard biochemical tests measure serological markers of disease, such as C-reactive protein, and RA-associated auto-antibodies, such as rheumatoid factor and anti-citrullinated protein antibodies. The information obtained from these markers does not, however, provide a complete picture of the disease and treatment efficacy. New biomarkers based on cytokine receptor complexes are promising for RA theragnostics.
\end{abstract}

\section{Rheumatoid arthritis biomarkers}

With the success of biologicals in the treatment of rheumatoid arthritis (RA), such as infliximab, adalimumab (anti-TNF), rituximab (anti-B-cell), and tocilizumab (anti-IL-6), the armamentarium of physicians is expanding so that personalized medicine is within our reach. The study of Satoko Takei and colleagues [1] in this issue of Arthritis Research \& Therapy describes a new serum biomarker with clear potential of becoming a valuable tool for the pharmacodiagnosis of RA. Biomarker tests that are currently available are failing to guide therapeutic decision making. C-reactive protein (CRP) and serum amyloid protein are sensitive markers of disease activity but blood levels often do not correlate with the obtained therapeutic effect. The same holds true for IgM rheumatoid factor and especially for anti-cyclic citrullinated protein antibodies, although the latter are

\footnotetext{
*Correspondence: Avandeloo@reumaumcn.nl
}

Rheumatology Research \& Advanced Therapeutics, Department of Rheumatology, Radboud University Nijmegen Medical Centre, Geert Grooteplein 28, 6525 GA Nijmegen, The Netherlands specific for RA and of great prognostic value for the outcome of disease [2]. It is important to monitor disease activity during therapy in order to adjust, change or even stop therapy when necessary. This is the reason that the search for new biomarkers that can be used to monitor or even predict therapeutic effectiveness is still ongoing.

\section{Biomarkers identified by -omics}

The major problem is that RA is a heterogeneous disease, with disease course and extent of connective tissue destruction varying considerably among patients. Histological evaluation of the inflamed synovium confirms the heterogeneity in RA, and cDNA microarray analysis of synovial tissue showed that, for example, STAT1 (signal tranducing and activator of transcription-1) gene expression distinguishes between RA subtypes [3]. For the diagnosis and management of disease, however, the genetic analysis of the inflamed synovial tissue is cumbersome. Blood is a highly dynamic environment, communicating with practically every tissue in the body, and is thus proposed as a 'sentinel tissue' that reflects disease progression in the body. Blood not only transports soluble biomarkers but because the leukocytes interact and communicate with practically every tissue, they bear rich information regarding inflammation and immune responses. Whole genome expression profiling of blood cells from RA patients has identified marker genes the expression of which predicts with $86 \%$ accuracy the response of infliximab in RA [4]. More importantly, only eight marker genes are needed to evaluate blood cells for a valid prediction. Another study showed that the expression of CD11c is a biomarker in monocytes to identify responders to abdalumimab [5]. Interestingly, the correlation of CD11c with response was lost when methotrexate was co-administered, showing the narrow window of $\mathrm{CD} 11 \mathrm{c}$ as a predictive transcriptional biomarker. Many other genes are significantly upregulated in RA peripheral blood mononuclear cells compared to healthy controls - for example, those encoding CD14 antigen, defensin-a1/3, and S100A proteins, which are of potential diagnostic and prognostic value for RA. Over the past decade, proteomics have yielded potential new 
candidates in the quest for better biomarkers for RA, including the S100 proteins, serum amyloid A, alpha 1-antitrypsin, and apolipoproteins in the blood [6]. In principle, carbohydrates, lipids and proteins (including enzymes, matrix proteins or their neoepitopes, autoantibodies, acute-phase proteins, chemokines, growth factors, cytokines and their inhibitors, and receptors) can be biomarkers for inflammation, connective tissue destruction, diagnosis and prognosis in RA (reviewed by Carrasco and Barton [7]).

\section{Soluble IL-18 receptor complex}

Cytokines and cytokine-related molecules play a key role in the pathogenesis of RA. Levels of TNF $\alpha$, the soluble TNF receptor-II, and IL- 6 are elevated in serum but, due to their short half-life and the complexity of the cytokine network, it remains to be determined whether they can be used as biomarkers in a clinical setting. IL-18 is a member of the IL-1 cytokine superfamily and plays a key role in the regulation of immunity and inflammation [8]. Its biological effect is regulated at different levels. IL-18 is synthesized as a larger precursor protein that requires caspase-1-mediated cleavage for activation. For IL-18 cell signaling, IL-18 binds to the IL-18 receptor (IL-18R) $\alpha$ with relatively low affinity and attracts the signal transducing IL-18R $\beta$ chain (also termed the IL-1R accessory protein-like chain) to form a functional receptor complex. In vivo, its biological activity is also dependent on secreted IL-18 binding proteins and the soluble forms of both its receptors: IL-18R $\alpha$ probably by enzymatic cleavage and IL-18R $\beta$ as an alternative splicing event. Their regulatory properties might be different as IL-18 binding protein ameliorates collagen-induced arthritis whereas soluble IL-18R $\beta$ aggravates it $[9,10]$. Previously, Bresnihan and colleagues [11] demonstrated raised serum levels of IL-18 and its binding protein in RA patients compared to psoriatic arthritis patients, but this did not seem to correlate with response to therapy with methotrexate, whereas CRP levels did. Interestingly, IL-18 protein expression in synovial tissue did correlate with serum CRP and disease activity in inflammatory arthritis [12], indicating a local role in the pathophysiology of disease. A comparative study of different biomarkers, either circulating or expressed in the synovial tissue, showed the utility of serum tissue inhibitor of metalloproteinases (TIMP) as predictive for a later therapeutic response to anakinra [13]. This study confirmed previous findings that serum IL-18 correlates poorly with disease activity and treatment response but is highly predictive for radiographic progression of the disease [13]. The study of Takei and colleagues [1] demonstrates that the systemic soluble IL-18R $\alpha$ complex, which in vitro exhibits antagonistic activity, probably also contains a dimeric IL-18 protein and the soluble form of the IL-18R $\beta$ chain.
The serum levels of this complex were significantly higher in patients with RA and adult-onset Still's disease than in healthy controls and osteoarthritis and systemic lupus erythematosus patients. Moreover, treatment of RA patients with the TNF inhibitor etanercept resulted in a significant improvement in serum levels of soluble IL$18 R \alpha$ complex. It remains to be seen whether the soluble IL-18R $\alpha$ complex can be used for the evaluation of joint damage or disease activity but even so it could be useful for the diagnosis of RA The soluble IL-18R $\alpha$ complex as a biomarker may capture the complexity of the inflammatory process: the shedding of membrane IL-18R $\alpha$ as a marker of enhanced proteolytic activity; the activation and release of IL-18 by the inflammasome as a marker of innate immunity; and the alternatively spliced soluble IL-18R $\beta$, which is mainly expressed in the lymphoid organs and regulates IL-18-driven T-cell immunity [10]. Currently, CRP is still a useful and reliable marker for disease activity and treatment response in the clinic. However, it is recognized that combinations of biomarkers will greatly enhance the power for diagnosis and the soluble IL-18R $\alpha$ complex may be useful in this regard for RA, but longitudinal studies and crosssectional analysis are warranted.

\section{Abbreviations}

CRP, C-reactive protein; IL, interleukin; IL-18R, interleukin-18 receptor; RA, rheumatoid arthritis; TNF, tumor necrosis factor.

Competing interests

The author declares that he has no competing interests.

Published: 27 April 2011

\section{References}

1. Takei S, Hoshino T, Matsunaga K, Sakazaki Y, Sawada M, Oda H, Takenaka S-I, Imaoka H, Kinoshita T, Honda S, Ida S, Fukuda T-A, Aizawa H: Soluble interleukin-18 receptor complex is a novel biomarker in rheumatoid arthritis. Arthritis Res Ther 2011, 13:R52.

2. Van Venrooij WJ, van Beers JJ, Pruijn GJ: Anti-CCP antibody, a marker for the early detection of RA. Ann N Y Acad Sci 2008, 1143:268-285

3. Van der Pouw Kraan TC, an Gaalen FA, Kasperkovitz PV, Verbeet NL, Smeets TJ, Kraan MC, Fero M, Tak PP, Huizinga TW, Pieterman E, Breedveld FC, Alizadeh $A A$, Verweij CL: RA is a heterogeneous disease: evidence for differences in the activation of the STAT-1 pathway between rheumatoid tissues. Arthritis Rheum 2003, 48:2132-2145.

4. Julià A, Erra A, an Gaalen FA, Kasperkovitz PV, Verbeet NL, Smeets TJ, Kraan MC, Fero M, Tak PP, Huizinga TW, Pieterman E, Breedveld FC, Alizadeh AA, Verweij $C L$ : An eight-gene blood expression profile predicts the response to infliximab in RA. PLoS One 2009, 4:e7556.

5. Stuhlmüller B, Häupl T, Hernandez MM, Grützkau A, Kuban RJ, Tandon N, Voss JW, Salfeld J, Kinne RW, Burmester GR: CD11c as a transcriptional biomarker to predict response to anti-TNF monotherapy with adalimumab in patients with RA. Clin Pharmacol Ther 2010, 87:311-321.

6. Vanarsa K, Mohan C: Proteomics in rheumatology: the dawn of a new era. F1000 Med Rep 2010, 2:87.

7. Carrasco R, Barton A: Biomarkers of outcome in rheumatoid arthritis. Rheumatology Reports 2010, 2:26-38.

8. Dinarello CA: Interleukin-18 and the treatment of rheumatoid arthritis. Rheum Dis Clin North Am 2004, 30:417-434.

9. Plater-Zyberk C, Joosten LA, Helsen MM, Sattonnet-Roche P, Siegfried C, Alouani S, van de Loo FA, Graber P, Aloni S, Cirillo R, Lubberts E, Dinarello CA, van Den Berg WB, Chvatchko Y: Therapeutic effect of neutralizing 
endogenous IL-18 activity in the collagen-induced model of arthritis. J Clin Invest 2001, 108:1825-1832.

10. Veenbergen S, Smeets RL, Bennink MB, Arntz OJ, Joosten LA, van den Berg $W B$, van de Loo FA: The natural soluble form of IL-18 receptor beta exacerbates collagen-induced arthritis via modulation of T-cell immune responses. Ann Rheum Dis 2010, 69:276-283.

11. Bresnihan B, Roux-lombard P, Murphy E, Kane D, FitzGerald O, Dayer J-M Serum interleukin 18 and interleukin 18 binding protein in rheumatoid arthritis. Ann Rheum Dis 2002, 62:726-729.

12. Rooney T, Murphy E, Benito M, Rou-Lombard P, FitxGerald O, Dayer J-M, Bresnihan B: Synovial tissue interleukin-18 expression and the response to treatment in patients with inflammatory arthritis. Ann Rheum Dis 2004, 63:1393-1398
13. Rooney T, Roux-Lombard O, Veale DJ, FitzGerald O, Dayer J-M, Bresnihan B: Synovial tissue and serum biomarkers of disease activity, therapeutic response and radiographic progression: analysis of a proof-of-concept randomized clinical trial of cytokine blockade. Ann Rheum Dis 2010, 69:706-714.

doi:10.1186/ar3308

Cite this article as: van de Loo FAJ: Soluble IL-18 receptor complex: a new star in the firmament of rheumatoid arthritis diagnosis? Arthritis Research \& Therapy 2011, 13:111. 